\title{
Carbon Sequestration in Coffee Agroforestry of Barbere District, Bale Zone, Southeastern Ethiopia: Implications for Climate Change Mitigation
}

\author{
Kefa Feye Garedew ${ }^{1^{*}} \quad$ Kassahun Ture Beketie $^{2} \quad$ Dejene Worku Deffere ${ }^{1}$ \\ 1.College of Natural and Computational Science, Department of Environmental Science, Madda Walabu \\ University, P.O. Box 247,Bale-Robe, Ethiopia \\ 2. Center for Environmental Science, School of Natural and Computational Science Addis Ababa University. \\ Addis Ababa, Ethiopia
}

\begin{abstract}
Climate change has become one of the most challenges facing the global community today. Human activities, particularly the burning of fossil fuels and deforestation, have increased the level of greenhouse gases, major contributors to global warming in the atmosphere. In spite of this hard fact; there was a growing need to develop strategies that will reduce current levels of greenhouse gases in the atmosphere. One such mechanism is the sequestration of carbon by the agroforestry system. The objective of this study was to determine the above and below ground carbon sequestration potential of coffee agroforestry and indicating their contributions to climate change mitigation. The coffee agroforestry of the study area was divided into three-shade types: monoculture shade cover, intermediate shade covers and densely shaded grown comprises a total area of 261 ha, of which 16 samples from the three-shade categories were chosen using lottery method. A total of 48 quadrant plots were laid to sample the coffee agroforestry system. Plot of size $400 \mathrm{~m}^{2}$ was used to measure the shade trees and coffee shrubs. Shade trees with $\geq 2.5 \mathrm{~cm}$ diameter at breast height were recorded, Coffee shrubs were measured in each $20 \mathrm{~m} X 20 \mathrm{~m}$ quadrant plot with stem diameter at $15 \mathrm{~cm}$ from the ground. Regression equations for estimation of AGB and BGB were established. Results indicate the coffee agroforestry production system that stores the most amount of carbon per hectare in its AGC and BGC was densely Shade $\left(65.69 \pm 6.27 \mathrm{Mg} \mathrm{C} \mathrm{ha}^{-1}\right)$, employing a variety of shade-tree species in three distinct layers. Conversely, the shaded monoculture with low structural complexity in its shade layer stores the least carbon $\left(28.85 \pm 3.93 \mathrm{Mg} \mathrm{Cha}^{-1}\right)$. The carbon-stock of the intermediate shade cover examined falls within this range. The study shows that the coffee agroforestry of Barbere district in southeastern Ethiopia plays a great role in the mitigation of climate change phenomenon by its good potential of carbon sequestration. This study recommends that the shade layer in coffee agroforestry be made denser for increased carbon storage and maintenance of biodiversity.
\end{abstract}

Key Terms: - Agroforestry, Biomass, Barbere, Carbon stock, Mitigation

DOI: $10.7176 /$ CER/11-9-01

Publication date:October $31^{\text {st }} 2019$

\section{INTRODUCTION}

Climate change has become one of the most horrible and hazardous environmental problems facing humankind and will be expected to continue for the coming generation [1]. The global shreds of evidence have shown that both terrestrial and oceanic temperature has drastically increased that of the last 100 years [2]). Global warming and climate changes seen today are being caused by the increase of $\mathrm{CO}_{2}$ and other greenhouse gas emissions by humans. This traps more heat in our atmosphere, which drives global warming and climate change [3]. Most of the increase in global temperature since the late 19th century has occurred in two distinct periods: 1910 to 1945 and since 1976. The rate of increase in temperature for both periods is about $0.15^{\circ} \mathrm{C}$ per decade [2].

Due to this tremendous increased temperature, climate change has recently become an urgent issue in various development, environment, and political forums at the national, regional, and international levels [4]. Even though, there is currently much public concern and scientific dialogue about the impacts of human-caused additions of $\mathrm{CO}_{2}$ and other greenhouse gases to the atmosphere and cycles of warming and cooling periods in our geologic history have greatly affected organisms and humans [5].

To overcome this problem, capturing $\mathrm{CO}_{2}$ is one of the most important global focuses [2]. The forest ecosystem is considered to be major sinks of carbon and can help to mitigate climate change $[6 ; 7 ; 8 ; 9]$ but the potential of agroforestry for global carbon sequestration has only recently acknowledged [10;11].

Agroforestry has been confirmed to be a hopeful mechanism of carbon sequestration [12] and also has strong implications for sustainable development as it offers a viable combination of carbon storage, food production, and environmental conservation. Therefore, agroforestry has the potential to act as carbon sinks and carbon storage pools while contributing to increased farm production, environmental conservation and poverty alleviation [13]. While agroforestry plays a vital role in removing carbon from the atmosphere through photosynthesis, the contribution of those coffee agroforestry systems, such as shade-grown coffee production systems, make to this 
end cannot be disregarded.

With coffee occupying over 10 million ha of land worldwide [14] and employing 20-25 million families in the production process, many of whom live in rural and impoverished communities [15;16;17). In Ethiopia, coffee is found growing 662,000 ha of which 496,000 ha are estimated to be productive, yielding an average of 350,000 tons of coffee beans per annum and accounting for more than $60 \%$ of Ethiopia's export earnings [18]. There are four coffee management systems in Ethiopia; Forest coffee, semi-forest coffee, garden coffee and plantation coffee, which respectively cover $5,35,50$ and $10 \%$ of the productive coffee area [19]. The potential coffee growing district in the Bale zone is Dello Mena, Barbere and Harena Bulluk which covers a land area of 35, 670 ha [20]. In the study area, the coffee is grown in agroforestry systems with low, medium and high structural diversity shading from several tree species.

Given enhanced carbon sequestration that occurs with tree planting and the practice of coffee, agro-forests have been recognized as feasible afforestation and reforestation strategies under the Clean Development Mechanism (CDM) of the Kyoto Protocol [21; 22]. However, there is little policy development encouraging the maintenance of current coffee agroforestry systems for the benefit of carbon sequestration. While programs such as REDD (the United Nations Program for Reducing Emissions from Deforestation and Forest Degradation) have been developed for tropical forests under threat, coffee agroforestry systems have yet to be included, largely a result of a complex set of factors that include climate change [23].

Shading practices provide some benefits to the coffee but also appear to be desirable environmental services as most of the forest vegetation in the coffee area has been cleared off and reforestation attempts have not been successful. Despite the widespread nature of this shade coffee system and the fact that farmers use little or no fertilizer in coffee production, there was no published work on carbon stock in shaded coffee agroforestry in Ethiopia. The provision of shade in coffee was a common agroforestry practice among farmers in the tropics. Besides producing a valuable crop to the farmers, coffee plays an important role in the carbon balance and sequestration of these tropical agroforestry systems. While the role of coffee in providing these ecosystem services has been studied in parts of tropics [24; 21], they have not been studied in Ethiopia. By recognizing the ecosystem services played by agroforestry in general and coffee in particular, local communities may be able to receive additional income and thus help to ensure that traditional agroforestry systems are maintained $[25 ; 21 ; 26]$. However, to determine the amount of carbon that is sequestered by coffee agroforestry in needed.

At the global and national level, researchers' and concerned organizations' at different countries and in different years, have been studying carbon sequestration and estimation of carbon stock in a coffee agroforestry system. However, previous studies more focused on the socio-economic benefits of Coffee but not on its high ecological versatility. Especially the study on the carbon storage capacity of Coffee agroforestry is not yet well studied. Thus, the study is important for sustainable Coffee agroforestry management to show the win-win strategies (economically and environmentally sound agroforestry management) can be achieved. So far, no research was done on Coffee agroforestry of Barbere district in general and estimation of carbon stock in particular. Therefore, this study was taken up to estimate the aboveground and belowground carbon stock of the Coffee agroforestry system.

\section{MATERIALS AND METHODS}

\subsection{Description of the Study Area}

This study was undertaken in Barbere District, Oromia National Regional State in Bale Zone. The district is located at a latitude between $6^{0} 24^{\prime} 50^{\prime \prime} \mathrm{N}$ to $6^{0} 55^{\prime} 20^{\prime} \mathrm{N}$ and Longitudes $39^{\circ} 51^{\prime} 15^{\prime \prime} \mathrm{E}$ to $40^{0} 21^{\prime} 45^{\prime \prime} \mathrm{E}$. It is situated west of Goro district, South of Sinana district, North of Delomena district and East of Goba district. The capital town of the district is Haro-dumal, which is located east of Robe town (capital of Bale zone) at $99 \mathrm{~km}$ and $530 \mathrm{~km}$ from the Addis Ababa to the southeast of the country. The total area of the district is $15650.711 \mathrm{~km}^{2}$. The area is part of the South East Ethiopian part of the mid-latitude with an altitude range 1170 to $1300 \mathrm{~m}$ a.sl within North to South and East to the west of the topography of the district ranges undulating to hilly landscape. About $45 \%$ of this district is plain; $37 \%$ is rugged and gorge, $18 \%$ is Mountainous. It has a minimum average annual temperature of $9^{0} \mathrm{c}$ and a maximum annual temperature of $23^{\circ} \mathrm{c}$ with average rainfall $1060-1150 \mathrm{~mm}$ per annum. Also, It has a bimodal rainfall season for the area, Belg usually extends mid -March to early August and Meher which extends early August to the end of December. The dominant soil categories in the district are Eurtric, combisols and Lithosols soil types. [20; 27] 


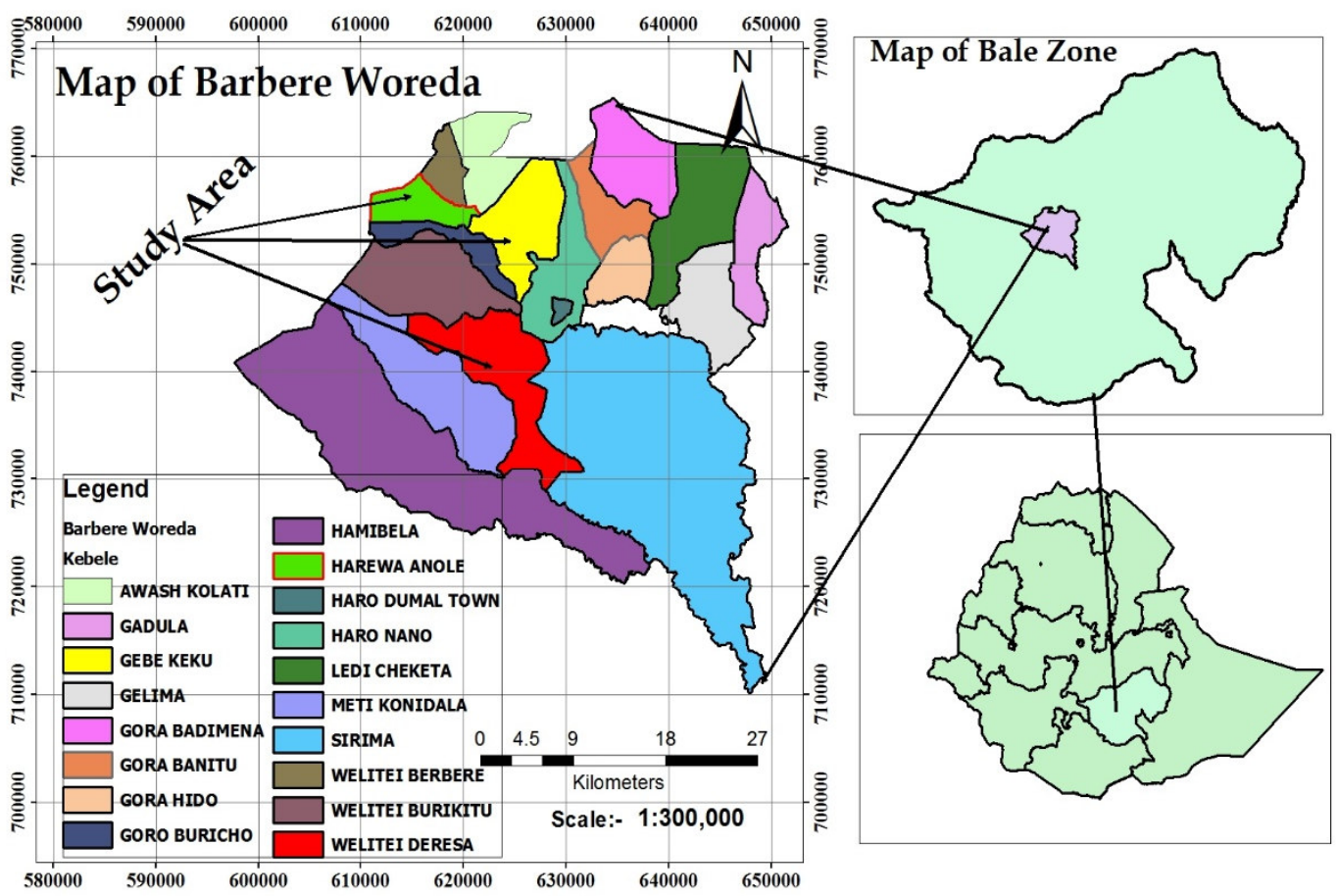

Figure 1. Map of the study area (Source: - Ethio - GIS, 2015).

\subsection{Study Design and Sampling Techniques \\ 2. 2.1. Preliminary Study}

A reconnaissance survey was carried out on 24-28 January, 2016 to collect basic information about the location, topography, climatic condition, land use land cover, vegetation and wild animals, population and approximate size of the study area from Barbere district finance and economic development office and agricultural development office.

Besides, a preliminary study was carried out to identify the shaded trees type on smallholder coffee agroforestry in the study area. This was conducted in consultation with Zonal and district agricultural experts and accompanied by experts working in local NGOs. Accordingly, three study sites namely Weltai-Deresa, Gebe-Keku, and Harewa-Anole kebele were selected using the lottery method to represent 15 coffee-producing kebeles in the district. Sampling sites (farms) for investigation were cover 261 ha out of 11,718 ha to represent the shade-grown coffee production systems in the study area.

\subsubsection{Study Design}

Primarily, three study areas namely Weltai-Deresa, Gebe-Keku, and Harewa-Anole, were selected using the lottery method to represent 15 coffee-producing kebeles in the district. Sampling sites (farms) for investigation were cover 261 ha out of 11718 ha to represent the most common shade-grown coffee production systems in the study area. More specifically, a gradient of the structural complexity of shade farms was created that includes three types of shade farms employing primarily shaded monoculture, intermediate shade cover and densely shade cover grown coffee agroforestry system classification schemes allow for the 48 plot sampling locations were given a rank according to structural complexity, which includes:

Rank 1: Low shade cover, or shaded monoculture: - This system incorporates only one shade layer primarily composed of legumes. It is a deciduous broad-leaved legume that is usually vegetatively propagated with stakes. Moreover, it is subject to intensive management including pruning for shade regulation.

Rank 2: Intermediate- shade covers: - This system incorporates two layers, one with leguminous species and the second employing species that provide significant shade due to minimal pruning and abundant foliage.

Rank 3: Densely shade cover: - This system employs a variety of shade species incorporated into three layers, including legumes, fruit trees, and timber-yielding species. This system may represent the highest structural diversity in the study area.

Systematic transect sampling techniques were conducted to layout transects along with the shade farm in coffee agroforestry. Sampling plot sized $20 \mathrm{~m} \times 20 \mathrm{~m}\left(400 \mathrm{~m}^{2}\right)$ was systematically assigned on each transect along with the shade farm [28]. The first sample plot was laid randomly, then the next sample plots were laid systematically along the line transects. A total of 10 transects was laid accordingly. The distances between the plots were $200 \mathrm{~m}$ which are adjusted using GPS and compass. A total of 48 plots were surveyed (16 plots x 3 sites 
on shade farm. i.e., 16 plots per kebele on shade farm categories) systematically. The GPS location of each plot was also recorded. The sample size determination also considered capturing the tree diversity; available resources and time frame work [29]. These plots were used to collect shade trees and coffee shrubs.

\subsection{Data Collection Methods}

\subsubsection{Shade Trees Inventory}

In each sample plot, shade trees with a diameter at breast height (DBH; taken at a height of $1.3 \mathrm{~m}) \geq 2.5 \mathrm{~cm}$ and recorded. When buttresses and other irregularities were present at $1.3 \mathrm{~m}$, it was measured $50 \mathrm{~cm}$ above the protuberances $[30 ; 28]$. A tree height $(\mathrm{H})$ was recorded using a hypsometer. The densities of trees were determined by counting the number of stems present at $1.3 \mathrm{~m}$ height and dividing by the total area sampled $\left(400 \mathrm{~m}^{2}\right)$. Trees on the border of the plot were measured if $\geq 50 \%$ of their basal area falls within the plot while trees on the edge of the plot will be excluded. Trees with their trunks inside the sampling plot and branches outside were also considered[31].

\subsubsection{Coffee Shrubs}

The coffee shrubs in the sample plot were counted and the height and diameter at $15 \mathrm{~cm}$ of each tree were recorded. The average height and DBH were calculated [32; 28]. All coffee shrubs sampled were analyzed separately from shade trees to minimize biases associated with density calculations. Coffee shrubs densities were estimated by counting the number of stems present and dividing by the total area sampled $\left(400 \mathrm{~m}^{2}\right)$.

\subsection{Estimation of Parameters}

\subsubsection{Estimation of Aboveground Carbon Stock (AGC)}

[34] defined allometric equations as a statistical relationship between key characteristic dimensions of the tree that are fairly easy to measure, DBH or height, and other properties that are more difficult to assess, such as aboveground biomass. For coffee agroforestry land-use systems, allometric models were used to estimate aboveground carbon stocks of all measured shade trees and coffee shrubs. Each of the allometric models utilized incorporated DBH measurements in the determination of above-ground biomass. Models described for shade trees were used to calculate the biomass of aboveground $[32 ; 28]$

To estimate the aboveground biomass of the shade trees employed in the sampled farms, the following regression equation was used:

$\log (\mathrm{AGB})=-0.9578+2.3408 * \log (\mathrm{D})$--------- (Equation 1$)$

Where $\mathrm{AGB}=$ aboveground biomass $\left(\mathrm{Mg} \mathrm{ha}^{-1}\right), \mathrm{D}=\mathrm{DBH}(\mathrm{cm})$.

This equation was developed by [28] and it was chosen because it was developed by destructively sampling shade trees from coffee Agroforestry and coffee agro-ecosystem with almost similar characteristics and employing similar shade species to those examined in another study area. The most accurate method to estimate the biomass of shade trees in a given region is to destructively sample a significant number of them and oven-dry their components [35].

Estimation of aboveground carbon content

The aboveground biomass of shade trees $\left(\mathrm{Mg} \mathrm{ha}^{-1}\right)$ was converted to carbon-stock $\left(\mathrm{Mg} \mathrm{C} \mathrm{ha}^{-1}\right)$ by applying the equation.

$\mathrm{AGC}=\mathrm{AGB} \times \mathrm{FC}$

Where $\mathrm{AGC}=$ Aboveground Carbon stored by shade trees $\left(\mathrm{Mg} \mathrm{C} \mathrm{ha}^{-1}\right), \mathrm{AGB}=$ Aboveground biomass of shade trees $\left(\mathrm{Mg} \mathrm{ha} \mathrm{h}^{-1}\right), \mathrm{FC}=$ Fraction of Carbon in biomass was estimated by multiplying of $0.5[36$; 1$]$, while multiplication factor 3.67 is used to estimate $\mathrm{CO}_{2}$ equivalent [37].

The Aboveground biomass of the coffee shrubs was estimated by applying the following equation [28]:

$\mathrm{LN}(\mathrm{AGB})=-2.39287+0.95285 * \mathrm{LN}(\mathrm{D})+1.2693 * \mathrm{LN}(\mathrm{H})$-------- (Equation 3)

Where $\mathrm{AGB}=$ Aboveground biomass, $\mathrm{D}=\mathrm{DBH}(\mathrm{cm}$ at $15 \mathrm{~cm}$ height $), \mathrm{H}=$ height $(\mathrm{m})$.

Again, this equation provides the best method for estimating the biomass of coffee shrubs sampled in another study, since coffee variety, the density of planting and management conditions are similar among other studies. The aboveground biomass of coffee shrubs $\left(\mathrm{Mg} \mathrm{ha}^{-1}\right)$ was converted to carbon-stock $\left(\mathrm{Mg} \mathrm{C} \mathrm{ha}^{-1}\right)$ by applying equation:-

$\mathrm{AGC}=\mathrm{AGB} \times \mathrm{FC}$ (Equation 4)

Where: $\mathrm{AGC}=$ Above Ground Carbon stored by coffee shrubs $\left(\mathrm{Mg} \mathrm{C}\right.$ ha $\left.{ }^{-1}\right), \mathrm{AGB}=$ Above Ground Biomass of coffee shrubs $\left(\mathrm{Mg} \mathrm{ha}^{-1}\right), \mathrm{FC}=$ Fraction of Carbon in biomass was estimated by multiplying of 0.5 (36; 1] while multiplication factor 3.67 is used to estimate $\mathrm{CO}_{2}$ equivalent [37].

\subsubsection{Estimation of Belowground Carbon Stock (BGC)}

Belowground biomass estimation is much more difficult and time-consuming than estimating aboveground biomass [38]. Roots play an important role in the carbon cycle as they transfer a considerable amount of carbon to the ground, where it may be stored for a relatively long period. The plant uses part of the carbon in the roots to increase the total tree biomass through photosynthesis, although carbon is also lost through respiration, exudation, 
and decomposition of the roots. For shade trees and coffee shrubs, the carbon present in living biomass was assumed to be $50 \%[35 ; 40]$. The biomass of roots was estimated by applying an allometric model developed by [39]

$\mathrm{BGB}=\exp (-1.0587+0.8836(\mathrm{Ln}$ AGB $)$ (Equation 5)

Where $\mathrm{BGB}=$ Belowground biomass $\left(\mathrm{Mg} \mathrm{ha}^{-1}\right), \mathrm{AGB}=$ Aboveground biomass $\left(\mathrm{Mg} \mathrm{ha}^{-1}\right)$.

To estimate the carbon content in belowground biomass of shade tree and coffee shrubs

$\mathrm{BGC}=\mathrm{BGB} \times \mathrm{FC}$ (Equation 6)

Where: BGC - Below Ground Carbon, BGB- Belowground biomass, FC- Fraction of carbon in biomass was estimated by multiplying of $0.5[36 ; 1]$ while multiplication factor 3.67 is used to estimate $\mathrm{CO}_{2}$ equivalent[37].

\subsection{Data analysis}

The collected data was organized and recorded on the excel data sheet. The data obtained from DBH, diameter, and height of each shade trees and coffee shrubs were analyzed using Statistical analyses were carried out using Microsoft excel of 2010 and Origin software 6.1 version. Analysis of variance (one way ANOVA), was used to determine statistically significant differences of carbon stocks along with shade tree categories for each carbon pool. Differences at the 0.05 level were reported as statistically significant.

\section{RESULTS AND DISCUSSION}

\subsection{RESULTS}

\subsection{Coffee Shade Trees}

Twenty-one shade-tree species and 14 families were identified in a coffee agroforestry system. Including Acacia Abyssinica, Albizia gummifera,Albizia grandibracteata, Albizia schimperiana, Celtis Africana, Cordia Africana, Croton macrostachyus, Erythrina brucei, Fagaropsis angolensis, Ficus vasta, Ficus sur, Hagenia Abyssinia, Mangifera Indica, Millettia ferruginea, Musa sapientum, Olea welwitschii, Persea Americana, Podocarpus falcatus, Pouteria adolfi-friederici, Sapium ellipticum and Syzygium guineense.

In conversations with coffee growers, many of the shade-tree species inventoried were identified as important sources of fuel-wood, medicine or fruit for sale on the local market. The low shade cover or shaded monoculture displays the least structural diversity (low diversity) in the study area with an almost uniform shade layer (Rank 1). The intermediate shade covers display intermediate diversity (medium diversity), employing one leguminous shade layer and one layer usually composed of timber and fruit-yielding trees (Rank 2). Lastly, the dense shade cover (diversified shade cover) displays the greatest diversity of species that are incorporated into three distinct layers (Rank 3).

\subsection{Carbon Stock along Shade Trees and Coffee Shrubs.}

\subsubsection{Aboveground Biomass and Carbon Stock of Shade Trees}

The biomass estimation method was used to determine the biomass and the carbon stock of the shade tree in the study area of coffee agroforestry. The result shows that the above-ground biomass of the shade tree ranged from $\left(25.96 \pm 2.18 \mathrm{Mg} \mathrm{ha}^{-1}\right)$ in monoculture shaded cover to $\left(64.29 \pm 3.29 \mathrm{Mg} \mathrm{ha}^{-1}\right)$ in densely shade cover. The aboveground biomass of the shade tree in the intermediate shade cover examined falls within this range. The average aboveground biomass of the study area was recorded $\left(48.93 \pm 17.13 \mathrm{Mgha}^{-1}\right)$.

The aboveground biomass carbon stock of the shade tree in the coffee agroforestry production systems examined ranges from $\left(12.98 \pm 1.13 \mathrm{Mg} \mathrm{C} \mathrm{ha}^{-1}\right)$ in monoculture shaded cover(MSC) to $\left(32.14 \pm 1.64 \mathrm{Mg} \mathrm{C} \mathrm{ha}^{-1}\right)$ in densely shaded cover (DSC) in the study area. The aboveground carbon-stock of a shade tree in the intermediate shade cover (ISC) examined falls within this range. The mean aboveground biomass carbon stock of the shade tree in the study area was $\left(24.48 \pm 8.56 \mathrm{Mg} \mathrm{C} \mathrm{ha}^{-1}\right)$. Statistically at the 0.05 level, the means were significantly different for above-ground carbon stock in the shade tree of shade type $(\mathrm{F}=450.91645, p=0)$ (Table 5), thus an overall increasing trend with increasing shade tree diversity. The aboveground biomass carbon stock carbon dioxide $\left(\mathrm{CO}_{2} \mathrm{e}\right)$ sequestration of a shade tree in coffee agroforestry of the study area ranged from $\left(47.63 \pm 4.14 \mathrm{Mg} \mathrm{C}^{-1}\right)$ in shaded monoculture (MSC) to $\left(117.97 \pm 6.04 \mathrm{Mg} \mathrm{C} \mathrm{ha}^{-1}\right)$ in densely shaded cover (DSC). The mean aboveground biomass carbon stock of the shade tree in coffee agroforestry carbon dioxide $\left(\mathrm{CO}_{2} \mathrm{e}\right)$ sequestration of the study area was $89.78+31.44 \mathrm{Mg} \mathrm{C} \mathrm{ha}^{-1}$.

Table 1 . Aboveground biomass and carbon stock of shade trees

\begin{tabular}{llll}
\hline Shade type & AGB $\left(\mathbf{M g ~ h a}^{-\mathbf{1}}\right)$ & AGC $\left(\mathbf{M g ~ C ~ h a} \mathbf{~ h a}^{-\mathbf{1}}\right)$ & $\begin{array}{l}\mathbf{C O}_{\mathbf{2}} \text { Equivalent } \\
\left(\mathbf{M g ~ C ~ h a}^{-\mathbf{1}}\right)\end{array}$ \\
\hline DSC & $64.29 \pm 3.29$ & $32.14 \pm 1.64$ & $117.97 \pm 6.04$ \\
ISC & $56.53 \pm 5.26$ & $28.26 \pm 2.63$ & $103.74 \pm 9.66$ \\
MSC & $25.96 \pm 2.18$ & $12.98 \pm 1.13$ & $47.63 \pm 4.14$ \\
\hline Mean & $48.93 \pm 17.13$ & $24.48 \pm 8.56$ & $89.78 \pm 31.44$ \\
\hline
\end{tabular}




\subsubsection{Belowground Biomass and Carbon Stock of Shade Trees}

The belowground biomass of shade trees in this study area ranges from $\left(21.88 \pm 1.99 \mathrm{Mg} \mathrm{ha}^{-1}\right)$ in monoculture shade cover to $\left(55.74 \pm 2.91 \mathrm{Mg} \mathrm{ha}^{-1}\right)$ in densely shade cover. The belowground biomass of the shade tree in the intermediate shade cover examined falls within this range. The average belowground biomass stock was $(42.17 \pm$ 15.14 $\left.\mathrm{Mg} \mathrm{ha}^{-1}\right)$.

The biomass of the belowground helps to determine the belowground biomass carbon stock of the shade tree in coffee agroforestry of the study area. The belowground biomass carbon stock of shade tree in coffee agroforestry of the study area examined ranges from $\left(10.94 \pm 0.99 \mathrm{Mg} \mathrm{C} \mathrm{ha}^{-1}\right)$ in monoculture shade cover to $(27.87 \pm 1.44 \mathrm{Mg}$ $\mathrm{C} \mathrm{ha}^{-1}$ ) in densely shade cover. The belowground carbon stock of the shade tree in the intermediate shade cover examined falls within this range. The mean belowground biomass carbon was $\left(21.08 \pm 7.57 \mathrm{Mg} \mathrm{C} \mathrm{ha}^{-1}\right)$. Statistically at the 0.05 level, the means were significantly different for belowground carbon stock of shade tree in shade type $(\mathrm{F}=450.9127, p=0)$ (Table 5), thus an overall increasing trend with increasing shade tree diversity. The belowground biomass carbon stock and carbon dioxide $\left(\mathrm{CO}_{2}\right.$ e) sequestration of a shade tree in coffee agroforestry of the study area ranged from $\left(40.15 \pm 3.66 \mathrm{Mg} \mathrm{Cha}^{-1}\right)$ in shaded monoculture to $(102.30 \pm 5.34 \mathrm{Mg}$ $\left.\mathrm{Cha}^{-1}\right)$ in densely shaded cover. The mean belowground biomass carbon stock of the shade tree in coffee agroforestry carbon dioxide $\left(\mathrm{CO}_{2} \mathrm{e}\right)$ sequestration of the study area was $\left(77.39 \pm 27.78 \mathrm{Mg} \mathrm{Cha}^{-1}\right)$.

Table 2. Belowground biomass and carbon stock of shade trees

\begin{tabular}{|c|c|c|c|}
\hline Shade type & BGB ( Mg ha' $\left.{ }^{-1}\right)$ & BGC $(\mathrm{Mg} \mathrm{C} \mathrm{ha-1})$ & $\begin{array}{l}\mathrm{CO}_{2 \mathrm{e}} \text { Equivalent } \\
\left(\mathrm{Mg} \mathrm{C} \mathrm{ha}^{-1}\right)\end{array}$ \\
\hline DSC & $55.74+2.91$ & $27.87 \pm 1.44$ & $102.30 \pm 5.34$ \\
\hline ISC & $48.89 \pm 3.44$ & $24.44 \pm 2.32$ & $89.72 \pm 8.53$ \\
\hline MSC & $21.88 \pm 1.99$ & $10.94 \pm 0.99$ & $40.15 \pm 3.66$ \\
\hline Mean & $42.17 \pm 15.14$ & $21.08+7.57$ & $77.39 \pm 27.78$ \\
\hline
\end{tabular}

The shade tree category that stores a large amount of above and belowground biomass carbon stock was densely Shaded cover, which employs a variety of shade tree species incorporated into three distinct layers including legumes, fruit trees, and timber-yielding species. Besides, this shade tree category represents the highest structural diversity seen in the study area and the highest corresponding carbon stock due to the greater potential of the shade trees employed for other purposes or because of the tree's large DBH, height and wood density. On the contrary, the shade tree category that stores the smallest amount of carbon stock in coffee agroforestry system of the study area was monoculture shaded cover. This system represents a low shade cover mode of production, with low structural diversity and incorporating only one leguminous shade layer subject to pruning for shade regulation which attributes to the low biomass and wood density. Intermediate shade cover incorporating two shade layer, display a carbon stock compared to that of densely shaded cover due to the large stature potential of an intermediate shade tree.

\subsubsection{Aboveground Biomass and Carbon Stock of Coffee Shrubs}

The above-ground biomass of coffee shrubs was ranged from $\left(5.80 \pm 1.87 \mathrm{Mg} \mathrm{ha}^{-1}\right)$ in monoculture shaded cover to $\left(6.60 \pm 2.31 \mathrm{Mg} \mathrm{ha}^{-1}\right)$ in densely shade cover. The aboveground biomass of coffee shrubs in the intermediate shade cover examined falls within this range. The average aboveground biomass coffee shrubs of the study area were recorded $\left(6.19 \pm 2.13 \mathrm{Mg} \mathrm{ha}^{-1}\right)$.

The aboveground biomass carbon stock of coffee shrubs in the coffee agroforestry production systems examined ranges from $\left(2.90 \pm 0.96 \mathrm{Mg} \mathrm{C} \mathrm{ha}^{-1}\right)$ in monoculture shaded cover $\left(3.30 \pm 1.15 \mathrm{Mg} \mathrm{C}^{-1}\right)$ in densely shaded cover in the study area. The aboveground carbon stock of coffee shrubs in the intermediate shade cover examined falls within this range. The mean aboveground biomass carbon stock of coffee shrubs in the study area was $\left(3.09 \pm 1.06 \mathrm{Mg} \mathrm{C}^{-1}\right)$. Statistically at the 0.05 level, the means were not significantly different for above ground carbon stock of Coffee shrubs in shade type $(\mathrm{F}=0.54571, p=0.58321)$ (Table 5). The aboveground biomass carbon stock carbon dioxide $\left(\mathrm{CO}_{2} \mathrm{e}\right)$ sequestration of coffee shrubs in coffee agroforestry of the study area ranged from $\left(10.65 \pm 3.55 \mathrm{Mg} \mathrm{C} \mathrm{ha}^{-1}\right)$ in shaded monoculture to $\left(12.11 \pm 4.24 \mathrm{Mg} \mathrm{C}^{-1}\right)$ in densely shaded cover. The mean aboveground biomass carbon stock of coffee shrubs in coffee agroforestry carbon dioxide $\left(\mathrm{CO}_{2} \mathrm{e}\right)$ sequestration of the study area was $\left(11.35 \pm 3.91 \mathrm{Mg} \mathrm{C} \mathrm{ha}^{-1}\right)$.

Table 3. Aboveground biomass and carbon stock of coffee shrubs

\begin{tabular}{llll}
\hline Shade type & AGB $\left(\mathrm{Mgha}^{-1}\right)$ & AGC(MgCha & \\
\hline DSC & $6.60 \pm 2.31$ & $3.30 \pm 1.15$ & $\begin{array}{l}\mathrm{CO}_{2} \text { Equivalent } \\
\left(\mathrm{Mg} \mathrm{C} \mathrm{ha}^{-1}\right)\end{array}$ \\
ISC & $6.16 \pm 2.19$ & $3.08 \pm 1.09$ & $12.11 \pm 4.24$ \\
MSC & $5.80 \pm 1.87$ & $2.90 \pm 0.96$ & $11.30 \pm 4.02$ \\
\hline Mean & $6.19 \pm 2.13$ & $3.09 \pm 1.06$ & $10.65 \pm 3.55$ \\
\hline
\end{tabular}

\subsubsection{Belowground Biomass and Carbon Stock of Coffee Shrubs}

The belowground biomass of coffee shrubs in this study area ranges from $\left(4.07 \pm 1.71 \mathrm{Mg} \mathrm{ha}^{-1}\right)$ in monoculture shade cover to $\left(4.77 \pm 2.04 \mathrm{Mg} \mathrm{ha}^{-1}\right)$ in densely shade cover. The belowground biomass of coffee shrubs in the 
intermediate shade cover examined falls within this range. The average belowground biomass stock of coffee shrubs was $\left(4.41 \pm 1.88 \mathrm{Mg} \mathrm{ha}^{-1}\right)$.

The biomass of belowground helps to determine the belowground biomass carbon stock of coffee shrubs in coffee agroforestry of the study area. The belowground biomass carbon stock of coffee shrubs in coffee agroforestry of the study area examined ranges from $\left(2.03 \pm 0.85 \mathrm{Mg} \mathrm{Cha}^{-1}\right)$ in monoculture shade cover to $(2.38$ $\left.\pm 2.04 \mathrm{Mg} \mathrm{C} \mathrm{ha}^{-1}\right)$ in densely shade cover. The belowground carbon stock of coffee shrubs in the intermediate shade cover examined falls within this range. The mean belowground biomass carbon stock was $(2.20 \pm 0.94 \mathrm{Mg}$ $\left.\mathrm{C} \mathrm{ha}^{-1}\right)$. Statistically at the 0.05 level, the means were not significantly different for belowground carbon stock of Coffee shrubs in shade type $(\mathrm{F}=0.54576, p=0.58319)$ (Table 5$)$. The belowground biomass carbon stock carbon dioxide $\left(\mathrm{CO}_{2} \mathrm{e}\right)$ sequestration of coffee shrubs in coffee agroforestry of the study area ranged from $(7.47 \pm 3.14$ $\left.\mathrm{Mg} \mathrm{Cha}^{-1}\right)$ in shaded monoculture to $\left(8.76 \pm 3.74 \mathrm{Mg} \mathrm{Cha}^{-1}\right)$ in densely shaded cover. The mean belowground biomass carbon stock of coffee shrubs in coffee agroforestry carbon dioxide $\left(\mathrm{CO}_{2} \mathrm{e}\right)$ sequestration of the study area was $\left(8.09 \pm 3.45 \mathrm{Mg} \mathrm{C}^{-1}\right)$.

Table 4. Belowground biomass and carbon stock of coffee shrubs

\begin{tabular}{lccc}
\hline Shade type & BGB($\left(\mathrm{Mgha}^{-1}\right)$ & BGC $\left(\mathrm{MgCha}^{-1}\right)$ & $\begin{array}{c}\mathrm{CO}_{2} \text { Equivalent } \\
\left(\mathrm{Mg} \mathrm{Cha}^{-1}\right)\end{array}$ \\
\hline DSC & $4.77 \pm 2.04$ & $2.38 \pm 2.04$ & $8.76 \pm 3.74$ \\
ISC & $4.38 \pm 1.93$ & $2.04 \pm 0.96$ & $8.04 \pm 3.55$ \\
MSC & $4.07 \pm 1.71$ & $2.03 \pm 0.85$ & $7.47 \pm 3.14$ \\
\hline Mean & $4.41 \pm 1.88$ & $2.20 \pm 0.94$ & $8.09 \pm 3.45$ \\
\hline
\end{tabular}

In general speaking, the figures do not vary greatly among the shade tree category of coffee shrubs in coffee agroforestry systems, due to that, as most display almost similar coffee-plant density; height and DBH. Monoculture shaded cover displays the lowest coffee shrubs carbon-stocks, a factor attributable to lower coffee shrubs density in coffee agroforestry as compare to another shade cover. The results of this study indicate that the type of shade or structural complexity of the shade layer does not greatly influence coffee biomass. More specifically, shaded monocultures (low shade cover) contain lower coffee carbon stocks than those shades cover employing densely or multiple shade layers (Densely shade cover). Therefore, these results indicate that increased shade diversity does not negatively affect the growth and development of the coffee plant, even though more complex shade limits the amount of sunlight reaching the coffee shrubs. Likewise, shade complexity does not significantly restrict the density of coffee shrubs, thus resulting in similar coffee shrubs carbon-stocks between shade types in a coffee agroforestry system.

Table 5: Summary of values of significance for one-way ANOVA between Shade tree and coffee shrubs in Shade categories for AGC, BGC) (AGC: Above ground carbon; BGC: Below ground carbon).

\begin{tabular}{llll}
\hline Shade type & Carbon pools & F-value & p-value \\
\hline DSC, ISC, and MSC & AGC of shade tree & 450.92 & 0 \\
DSC, ISC, and MSC & AGC of Coffee shrubs & 0.55 & 0.58 \\
DSC, ISC, and MSC & BGC of shade tree & 450.91 & 0 \\
DSC, ISC, and MSC & BGC of Coffee shrubs & 0.54 & 0.58 \\
\hline
\end{tabular}

\subsection{DISCUSSIONS}

\subsubsection{Above and Belowground Carbon Stock in Coffee Agroforestry}

Traditionally, coffee is grown under the shade of natural unaltered forest canopy, where the composition and structure of the forest remain intact. However, like other agroforestry systems that employ a woody component, shade grew coffee agroforestry contribute to the removal of carbon from the atmosphere and its storage on land [28]. The Coffee agroforestry systems built-in this study stored considerable amounts of carbon in aboveground and belowground biomass carbon pool.

The total biomass values in coffee agroforestry of the study area $\left(57.71 \pm 7.71 \mathrm{Mg} \mathrm{ha}^{-1}\right)$ in monoculture shade cover to $\left(131.4 \pm 10.55 \mathrm{Mg} \mathrm{ha}^{-1}\right)$ in densely shade cover are higher than that of dry sub-tropical dry forests of (78 to $\left.90 \mathrm{Mg} \mathrm{ha}^{-1}\right)$ and $\left(115 \mathrm{Mg} \mathrm{ha}^{-1}\right)$ for African tropical mountain systems [41]. However, it was lower than the global average values for forest biomass and some tropical forest types. The mean total biomass of forests globally averages $\left(149 \mathrm{Mg} \mathrm{ha}^{-1}\right)$ [8], [42] reported a range in total biomass stocks for undisturbed, broadleaf tropical forests of (61 to $\left.176 \mathrm{Mg} \mathrm{ha}^{-1}\right)$ and lower than indigenous agroforestry system $\left(104.7 \mathrm{Mg} \mathrm{ha}^{-1}\right)$ in Enset system to (173.2 $\left.\mathrm{Mg} \mathrm{ha}^{-1}\right)$ in Enset- coffee system) in southeastern rift valley escarpment of Ethiopia[43].

The above ground carbon stock results fall within the range reported by [1] for the carbon-stock of shade

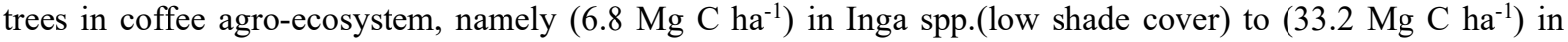
diversified shade cover. Similarly, the results reported in this study compare favorably with the shade tree aboveground biomass carbon-stock range of (1.9 to $\left.31.8 \mathrm{Mg} \mathrm{C} \mathrm{ha}^{-1}\right)$ reported by [32] and its mean aboveground carbon was almost similar with shade tree in coffee agroforestry of central valley of Costa Rica $\left(24.8 \mathrm{Mg} \mathrm{C} \mathrm{ha}^{-1}\right)$ 
reported by[44] However, the mean aboveground carbon stock reported in this study was comparable with coffee agroforestry system reported (Enset-coffee $59.2 \pm 21 \mathrm{Mg} \mathrm{C} \mathrm{ha}^{-1}$, Fruit-coffee $58.3 \pm 18.3 \mathrm{Mg} \mathrm{Cha}^{-1}$ ) in southeastern rift valley of Ethiopia [43].

The mean belowground carbon stock result reported in this study higher compared to that of the shade tree carbon stock in coffee agroforestry of Guatemala $\left(16.2 \mathrm{Mg} \mathrm{C} \mathrm{ha}^{-1}\right)$ and central Valley of Costa Rica $\left(4.8 \mathrm{Mg} \mathrm{C} \mathrm{ha-}^{-}\right.$ $\left.{ }^{1}\right)$ reported by [28], and [44] respectively. And Shade coffee plantation of Southwestern Togo (15 Mg C ha-1) reported by [21]. This difference can be attributed to a higher reported density of shade trees per hectare in that study, different local conditions, (including climate, soil, and management practices and allometric equation selection influencing that coffee agroforestry biomass. According to the authors, these factors have a significant effect on the overall biomass-productivity of coffee agroforestry.

Several studies have been investigated the biomass carbon stock of coffee shrubs in agro-ecosystems. The biomass carbon stock of coffee shrubs in this study area was higher compared to study reported for coffee shrubs carbon stock ranging from (1.4Mg Cha $\left.{ }^{-1}\right)$ in Inga spp. (low shade cover) to (3.5 $\left.\mathrm{Mg} \mathrm{Cha}^{-1}\right)$ in densely(diversified) shade cover in southern Costa Rica [1] coffee shrubs carbon stocks ranging from 0.2 to $2.8 \mathrm{Mg} \mathrm{C} \mathrm{ha}^{-1}$ [32], [45] report 3.93 $\mathrm{Mg} \mathrm{C} \mathrm{ha}^{-1}$ for coffee shrubs grown in association with Cordia alliodora in Turrialba, Costa Rica, [46] reports $8.4 \mathrm{Mg} \mathrm{C} \mathrm{ha}^{-1}$ in a coffee with por system in the Central Valley of Costa Rica and [47] 3.77.Mg Cha-1 in the coffee component of a study conducted in Guatemala.

The total biomass Carbon stocks of the shade tree and coffee shrubs in coffee agroforestry systems $\left(28.85 \pm 3.93-65.69 \pm 6.27 \mathrm{Mg} \mathrm{Cha}^{-1}\right)$ are within the range reported for agroforestry systems globally $(12-228 \mathrm{Mg}$ $\left.\mathrm{Cha}^{-1}\right)[48 ; 25]$, agrisilviculture systems in the humid tropical region of Africa (29-53 $\mathrm{Mg} \mathrm{Cha}^{-1}$ ) [25] and other agroforestry systems in the tropics $[49 ; 13 ; 26]$ However, our values were lower than reported for other traditional agroforestry systems in the tropics $[50 ; 51]$ and Cacao-based agroforestry systems in western and central Africa [52] The total biomass Carbon stocks of the shade tree and coffee shrubs in coffee agroforestry systems were low compared to in which coffee was grown (Enset-Coffee and Fruit-Coffee) and other coffee agroforestry systems $[21 ; 28 ; 43]$. But substantially higher than the range reported for agroforestry systems in sub-Saharan Africa (4.5$\left.19 \mathrm{Mg} \mathrm{C} \mathrm{ha}^{-1}\right)$ [53] and coffee-based agroforestry in southwestern Ethiopia $\left(62.23 \pm 17.1 \mathrm{Mg} \mathrm{Cha}^{-1}\right)$ reported by [54] But this is maybe due to the contribution of trees in our coffee agroforestry systems as compared to this area, local condition (climate, soil, management practices) and the allometric equation selection may have significant effect on the overall biomass carbon stock of coffee agroforestry.

\section{CONCLUSIONS AND RECOMMEDATIONS}

\subsection{CONCLUSIONS}

Climate change is a multi-faced global phenomenon. Addressing it requires the amalgamation of numerous disciplines and cooperation among nations. The study shows that the coffee agroforestry of Barbere district makes a significant contribution to carbon sequestration to mitigate climate change and therefore can generate carbon credits in Ethiopia. It's also expected that much income can be made earned by selling carbon credits in the carbon market through a clean development mechanism. A total of 21 different shade tree species and 15 families were recorded. The DBH and height distribution of shade trees in coffee agroforestry varied from species to species within the shade type of the study area.

The largest portion of the carbon is stored in the shade tree component as compare to coffee shrubs in coffee agroforestry system of the study area. Therefore, shade trees represent the largest and most important aboveground and belowground biomass carbon pool in a coffee agroforestry system in the study area. The carbon-stock of shade trees depends on the density of planting, species type and characteristics (including DBH, height and wood density). Therefore, carbon-stock is not only dictated by shade density and structural complexity, but also by the specific tree species involved. To increase the biomass of coffee agroforestry should not only focus on increasing the number of trees per hectare, but also on strategically choosing tree species that store carbon efficiently, such as timber species.

The above and below ground carbon stock (shade tree and coffee shrubs) of the coffee agroforestry production systems examined ranges from $\left(28.85 \pm 3.93\right.$ to $\left.65.69 \pm 6.27 \mathrm{Mg} \mathrm{C} \mathrm{ha}^{-1}\right)$. The shade tree category that stores the most carbon was the dense shade covers, which employs a variety of shade species incorporated into three distinct layers including legumes, fruit trees, and timber-yielding species. This system represents the highest structural diversity seen in the study area and the highest corresponding carbon stock due to the greater potential of the shade trees employed for different uses (higher volume and wood density). Conversely, the shade tree category that stores the least amount of carbon is coffee agroforestry was the low shade cover. This system represents a shaded monoculture mode of production, with low structural diversity and incorporating only one leguminous shade layer subject to pruning for shade regulation. Intermediate shade cover incorporating two shade layers, display medium carbon stocks depending on the shade species employed. More specifically, intermediate shade cover display a carbon-stock comparable to that of densely Shade. This is primarily attributable to the high biomass and wood density, the large stature potential of trees. Generally, the study shows that the coffee agroforestry of Barbere 
district in southeastern Ethiopia plays a great role in the mitigation of climate change phenomenon by its good potential of carbon sequestration.

\subsection{RECOMMEDATIONS}

Based on the findings of this study, the following recommendations were forwarded.

The amount of carbon sequestered in this study site was significant. In Ethiopia, there is a large amount of coffee agroforestry conserved in different parts of the country so conducting similar research in those resources is recommendable. To undertake further researches on different aspects, altitude, latitude, locality, climate, soil and elevation range (site quality) should be conducted for a coffee agroforestry system.

The economic valuation of $\mathrm{CO}_{2}$ needs to be done at the governmental level so that $\mathrm{CO}_{2}$ can be traded to enhance the national economy. Skill and training should be provided to the local people to enhance coffee plantation for sustainable coffee agroforestry management for the win-win strategies (economically and environmentally sound agroforestry management) can be achieved and also improve their livelihood. Public awareness should be raised about global climate change and the role of the coffee agroforestry system in mitigating climate change.

\section{Conflicts of Interest}

The authors did not declare any conflict of interest.

\section{REFERENCES}

[1] Polzot, C.L. (2004). Carbon storage in coffee agro-ecosystems of southern Costa Rica: potential applications for the Clean Development Mechanism.York University.

[2] IPCC, (2007).Climate Change, Synthesis report - Summary for policymakers. An Assessment of the Intergovernmental Panel on Climate Change

[3] UNEP, (2011). Climate Change Starter's Guidebook: An issues guide for education planners and practitioners. Paris: United Nations Educational, Scientific and Cultural Organization and the United Nations Environment Program.

[4] IPCC., 2006. Guidelines for national greenhouse gas inventories, presented by national greenhouse gas inventory program, IPCC/IGES, Hayama, Japan.

[5] Williams, J. W. (2006).Quaternary vegetation distributions. In the Encyclopedia of paleoclimatology and ancient environments. Earth Science Series, New York.

[6] UNFCCC, (1997). Kyoto Protocol to the Convention on Climate Change: Climate Change Secretariat. Bon Germany.

[7] FAO. (2005). Global Forest Resource Assessment (FRA). FAO Forestry Paper 147. Food and Agriculture Organization of the United Nations, Rome, Italy.

[8] FAO. (2010). Global forest resources assessment. The main report, FAO Forestry Paper 163. Rome, Italy.

[9] Pan, Y., Birdsey, RA., Fang, J., Phillips, OL., Shvidenko, A., Lewis, SL., Canadell, JG., Sitch, S., Hayes, D. (2011).A large and persistent carbon sink in the world's forests. Science. Vol, 333, pp. 988-993.

[10] Smith, P., Martino, D., Janzen, H., Kumar, P., Rice, C., Scholes, B., Sirotenko, O. (2007). Agriculture. In Climate Change 2007: Mitigation. Contribution of Working Group III to the Fourth Assessment Report of the Intergovernmental Panel on Climate Change. The United Kingdom and New York, NY, USA.

[11] Jose, S., and Bardhan, S. (2012). Agroforestry for biomass production and carbon sequestration: An overview. Agroforestry System. Vol, 86, pp. 105-111.

[12] Singh, T.P. and Lal, M. (2000). Carbon sequestration through farm forestry: a case from India. Indian Forester. Vol, 126, pp. 1257-1264.

[13] Pandey, D.N. (2002).Carbon sequestration in agroforestry systems. Climate Change Policy. Vol, 2, pp. 367377.

[14] FAO. (2009) FAOSTAT: productionlcrops. http. org/site/567/default.aspx\#ancor. Accessed 12 December (2011).

[15] Oxfam. (2001). Bitter coffee: how the poor are paying for the slump in coffee prices.

[16] Lewin, B., Giovannucci, D., Varangis, P. (2004). Coffee markets: new paradigms in global supply and demand. World Bank, Washington, DC.

[17] Jha, S., Bacon, C.M, Philpott, S.M., Rice, R.A., Me'ndez, V.E., La“derach, P. (2011). A review of ecosystem services, farmer livelihoods and value chains in shade coffee agro-ecosystems.

[18] Muleta, D., Assefa, F., Nemomissa, S. and Granhall, U.( 2007). Composition of coffee shad tree species and density of indigenous arbuscular mycorrhizal fungi (AMF) spores in Bonga natural coffee forest, southwestern Ethiopia. Forest Ecology and Management. Vol, 241, pp.145- 154.

[19] Labouisse, J.P., Bellachew, B., Kotecha, S. and Bertrand, B. (2008). Current status of coffee (Coffea arabica L.) genetic resources in Ethiopia: Implications for conservation. Genetic Resources and Crop Evolution. Vol, 
55, pp. 1079-1093.

[20] BZAO, (Bale Zone Agriculture Office). (2015). Bale-Robe, Ethiopia.

[21] Dossa, E.L, Fernandes ECM, Reid WS. (2008). above and belowground biomass, nutrient and carbon stocks contrasting an open-grown and a shaded coffee plantation. Agroforestry System. Vol, 72, pp. 103-115

[22] UNFCCC :(United Nations Framework Convention on Climate Change). (2006). Revised simplified baseline and monitoring methodologies for selected small-scale afforestation and reforestation activities under the clean development mechanism. Bonn, Germany.

[23] Ellis, E.A, Baerenklau K.A, Marcos-Martı'nez R, Cha'vez E. (2010). Land use-land cover change dynamics and drivers in a lowgrade marginal coffee growing region of Veracruz, Mexico. Agroforestry System. Vol, 80, pp. 61-84.

[24] Segura, M., Kanninen, M., Sua'rez, D. (2006). Allometric models for estimating the aboveground biomass of shade trees and coffee bushes grown together. Agroforestry System. Vol, 68, pp. 143-150.

[25] Albrecht, A. and Kandji, S.T. (2003). Carbon sequestration in tropical Agroforestry systems. Agriculture, Ecosystems, and Environment. Vol. 99, pp. 15 - 27.

[26] Soto-Pinto, L., Anzueto, M., Mendoza, J., Ferrer, GJ., de Jong, B. (2010). Carbon sequestration through Agroforestry in indigenous communities of Chiapas, Mexico. Agroforestry System. Vol, 78, pp. 39-51.

[27] BDFEDO, (Berbere District Finance and Economic Development Office). (2015). Berbere District Finance and Economic Development Office. Berbere, Harodumal.

[28] Schmitt-Harsh, M., Evans, T.P., Castellanos, E. and Randolph, J.C. (2012). Carbon stocks in coffee agroforests and mixed dry tropical forests in the western highlands of Guatemala.

[29] Picard, N., Saint-Andre, L., Henry, M. (2012). Manual for building tree volume and biomass allometric equations: from field measurement to prediction. Food and agricultural organization of the United Nations, Rome.

[30] Condit R. (1998). Tropical forests census plots. Springer, Berlin

[31] MacDicken, K. (1997). A Guide to monitoring carbon storage in Forestry and Agroforestry projects. Arlington (Ed): Winrock International Institute for Agriculture Development.

[32] Su'arez Pascua, (2002). Carbon stock of agroforestry in Matagalpa. Nicaragua.

[33] Walkley, A. and Black, I.A. (1994). An examination of the Degtjareff method for determining organic carbon in soils: Effect of variations in digestion conditions and inorganic soil constituents. Soil Science. Vol, 63, pp. 251-263.

[34] Bhishma, P.S., Shiva, S.P., Ajay, P., Eak, B.R., Sanjeeb, B., Tibendra, R.b., Shambhu, C., and Rijan, T.(2010). Forest Carbon Stock Measurement: Guidelines for measuring carbon stock in community managed forests. Kathmandu, Nepal.

[35] Brown, S. (1997). Estimating Biomass and Biomass Change of Tropical Forests: a Primer. FAO, Rome, Italy.

[36] IPCC.,(1997). Land use change and forestry. In: Revised 1996 IPCC Guidelines for National Greenhouse Gas Inventories: Reference Manual. Volume 3. Eds. Houghton, J.T., Meira Filho, L.G., Lim, B., Trenton, K., Mamata, I., Bonduki, Y., Griggs, D.J. and Callander, B.A., Intergovernmental panel on climate change.

[37] Pearson, T., Walker, S., and Brown, S. (2005). Sourcebook for land-use, land-use change and forestry projects. Win-rock International and the Bio-carbon fund of the World Bank. Arlington, USA. pp. 19-35.

[38] Geider, J.R., Delucia, H.E., Falkowsk, G.P., Finzi, C.A., Grime, P.J., Grace, J., Kana, M.T., Roche., (2001). Primary productivity of planet earth: biological determinants and physical constraints in terrestrial and aquatic habitats. Global Change Biology. Vol, 7, pp. 849-882.

[39] Cairns, M. A., Brown, S., Helmer, E. H. and Baumgardner, G. A. (1997). Root biomas allocation in the world's upland forests. Oecologia. Vol, 11, pp. 1-12.

[40] Penman, J., Gytarsky T., Kruger, D., Tanabe, K., Wagner, F. (2003). Good practice guidance for land use, land-use change, and forestry. IPCC National Greenhouse Gas Inventories Program and Institute for Global Environmental Strategies, Kanagawa, Japan.

[41] Aaron, R. and Gibbs, H.K. (2008). New IPCC Tier-1 Global Biomass Carbon Map for the Year 2000. Available online from the Carbon Dioxide Information Analysis Centre, Oak Ridge National Laboratory, Oak Ridge, Tennessee

[42] Brown, S., and Lugo, A.E., (1984). Biomass of tropical forests: A new estimate based on forest volumes. Science Vol, 22, pp. 1290-1293.

[43] Mesele, N. (2013). The indigenous Agroforestry systems of the south-eastern Rift Valley escarpment, Ethiopia: Their biodiversity, carbon stocks, and litter fall. The University of Helsinki.

[44] Häger, A. (2012). The effects of management and plant diversity on carbon storage in coffee agroforestry systems in Costa Rica. Agroforestry Systems. Vol, 86, pp. 159-174.

[45] Alpizar, L., Fassbender, H.W. and Heuvelop, J. (1985). Sistemas agroforestales de caffe (Coffea arabica) con laurel (Cordia alliodora) y con Por (Erythrina poeppigiana) en Turrialba, Costa Rica. I. Biomasa y reservas nutritivas. Turrialba. Vol, 35, pp. 233-242. 
[46] Fournier, L. (1996). Fijacin de carbono y diversidad biologica en el agroecosistema cafetero. Boletn Promecade, Vol, 71, pp. 7-13.

[47] Maquez, L. (1997). Validacin de Campo de los MØodos del Instituto Winrock para el Establecimiento de Parcelas Permanentes de Muestreo para Cuantificar Carbono en Sistemas Agroforestales. Guatemala: Universidad del Valle de Guatemala thesis.

[48] Dixon, R.K. (1995). Sistemas agroforestales y gases de invernadero. Agroforestería en las Américas. Vol, 7 , pp. 22-26.

[49] De Jong, B.H.J., Tipper, R. \& Taylor, J. (1997). A framework for monitoring and evaluating carbon mitigation by farm forestry projects: example of a demonstration project in Chiapas, Mexico. Mitigation and Adaptation Strategies for Global Change. Vol, 2, pp. 231-246.

[50] Kirby, K.R. and Potvin, C. (2007). Variation in carbon storage among tree species: Implications for the management of a small-scale carbon sink project. Forest Ecology and Management, Vol, 246, pp. 208-221.

[51] Roshetko, J.M., Lasco, R.D. and Angeles, M.SD. (2007). Smallholder Agroforestry systems for carbon storage. Mitigation and Adaptation Strategies for Global Change. Vol, 12, pp. 219-242.

[52] Duguma, B., Gockowski, J. and Bakala, J. (2001). Smallholder cacao cultivation in agroforestry systems of the west and central Africa: challenges and opportunities. Agroforestry Systems Vol, 51, pp. 177-188.

[53] Unruh, J.D., Houghton, R.A. and Lefebvre, P.A. (1993). Carbon storage in agroforestry: an estimate for subSaharan Africa. Climate Research.Vol, 3, pp. 39-52.

[54] Mohammed, A. and Bekele, L. (2014). Changes in Carbon stocks and sequestration potential under native forest and adjacent land use systems at Gera, southwestern, Ethiopia. 